\title{
Diversity and ecology of soil algae in broadleaf sacred grove and pine forest in East Khasi Hills, Meghalaya
}

\author{
C. M. Dirborne ${ }^{\varpi}$ and Papiya Ramanujam \\ Algal Ecology Laboratory, Centre for Advance Studies in Botany, Department of Botany, School of Life Sciences, \\ North-Eastern Hill University, Shillong, Meghalaya - 793022, India \\ 凶Correspondence author: cariedirborne@gmail.coms
}

\section{मेघालय की पूर्वी खासी पहाड़ियाँ के ब्रॉडलीफ पवित्र वन और चीड़ वनों में मृदा शैवाल की विविधता और पारिस्थितिकी}

\author{
सी. एम. डिखोर्न एवं पापिया रामानुजम
}

\section{सारांश}

वर्तमान अध्ययन में, मेघालय के पूर्वी खासी जिले में चीड़ वन व उपोष्णकटिबंधीय चौड़े पत्ते वाले दो पृथक वनों में (मावफलांग पवित्र वन) मृदा शैवाल वर्ग की विवेचना की गई है । वन सतह में प्रकाश उपलब्धता एवं मृदा भौतिक रसायन पैरामीटर की जांच कर ली गई है । दोनों वनों से मृदा शैवाल का कुल 124 टैक्सा अभिलेखित किया गया है । क्लोरोफाइटा, जैंथोफाइसी, इयूस्टीग्मामेटोफायसी अवयव का सर्वाधिक मात्रा $(72 \%-80 \%)$ रहा। मावफलोंग के पवित्र वन में साइनोबेक्टेरिया का अधिक मात्रा (21\%) एवं डायटम की कम मात्रा (2\%) जांची गई। जबकि चीड़ के वनों में डायटम की अधिक मात्रा (20\%) एवं साइनोबेक्टेरिया की कम मात्रा (13\%) जांची गई । दो वनों के प्रकार में शैवाल जाति का संयोजन काफी अलग है। प्रकाश और मृदा की विशेषताओं के साथ जातियों की विविधता के बीच संबंध ों से इंगित मिलता है कि पीएच. आर्द्रता की मात्रा, जैविक कार्बन एवं नाइट्रोजन के साथ वनस्पति ने शैवाल वर्ग के संयोजन में महत्वपूर्ण भूमिका निभाई है ।

\section{ABSTRACT}

In the present study, soil algal community inhabiting in two different forest types i.e., pine forest and subtropical broadleaf forest (Mawphlang sacred grove) in East Khasi Hills District of Meghalaya have been investigated. Light availability to the forest floor and soil physico-chemical parameters were examined. A total of 124 taxa of soil algae were recorded from both the forests. Members from Chlorophyta, Xanthophyceae, Eustigmatophyceae contributed the most (72\%-80\%). Mawphlang sacred grove was characterised by more abundance of Cyanobacteria (21\%) and less diatoms (2\%), while in pine forest diatoms abundance was high (20\%) and less Cyanobacteria (13\%). Algal species composition differed significantly between the two forest types. Correlation between species diversity with light and soil characteristics indicated that vegetation along with $\mathrm{pH}$, moisture content, organic carbon and nitrogen played important role in determining the composition of algal community.

Keywords: Soil Algae, Sacred Grove, Pine Forest, Moisture Content, Diatoms 


\section{INTRODUCTION}

Algal community of soils form one of the most sensitive biotic components and play significant roles in the ecological stability of soil systems (Megharaj \& al., 2000). They also form an integral part of soil ecosystems all over the world as they represent the significant autotrophic components of the biotic community of all soils. Algal community structure is influenced by specific climate condition, particular soil type and specific vegetation of the locality (Bohlen \& al., 2001). Canopy cover formed by the higher plants along with the physical and chemical characteristics of the soil affected the composition of the algal population in the forest floor (Bakieva \& al., 2012). Positive influences of nutrients, moisture content and the degree of soil compaction have been observed on the growth of soil algae (El-Gamal \& al., 2008).

Algae of temperate soils are well explored (Fujita \& Nakahara, 2006; El-Gamal \& al., 2008; Mansour \& Shaaban, 2010) those of certain tropical soils are also being explored recently. In tropical soils Rehakova \& al., (2011) observed the influence of altitude and vegetation type on the microalgal communities in Ladakh, while the colonisation of Cyanbacteria in desert soils of Thar desert as a function of agroecological conditions was reported by Bhatnagar \& al., (2008). Tropical wet soils are rich with algae unlike temperate soils where algal diversity is low (Lukesova 2001; Ray \& Thomas, 2013). The current investigation on the diversity and ecology of soil algae in subtropical moist broad-leafed forest patches of Mawphlang sacred grove and pine forest in East Khasi Hills, Meghalaya, aimed to generate basic data on soil algal communities in two different forest types which represent this biodiversity hot spot region.

\section{STUDY SITES}

The present study was carried out in Mawphlang sacred grove and pine forest during 2015-2016.

Mawphlang sacred grove situated about $25 \mathrm{~km}$ south of Shillong is an undisturbed subtropical broad-leafed forest patch lying at an altitude of $1815 \mathrm{~m}, 25^{\circ} 26^{\prime} \mathrm{N}$ and $91^{\circ} 44^{\prime}$ E. It has been preserved and protected by the khasi tribal community and have a religious significant. The common tree species recorded from this grove are members of the genus Castanopsis, Eleocarpus, Ficus, Myrica, Quercus and Symplocos. Soil in the grove is blackish brown in colour and is of sandy loam in texture. Due to thick tree canopy in the grove very low intensity of light ranging between 41-70 $\mu \mathrm{mol}$ photons $\mathrm{m}^{-2} \mathrm{~s}^{-1}$ penetrated to the forest floor. Litter in forest floor of Mawphlang sacred grove is thicker as compared to pine forest mostly consist of leaves, flowers, fruits and twigs from among which the leaves form the major mass.

Subtropical pine forest in Shillong is unique and the present site was selected inside the North Eastern Hill University campus, located at an altitude of $1415 \mathrm{~m}$, $25^{\circ} 36^{\prime} \mathrm{N}$ and $91^{\circ} 53^{\prime} \mathrm{E}$. Pinus kesiya Royle ex Gordon is the dominant tree species in this area. Other species of Eucalyptus sp, Jacaranda mimosifolia D. Don, Alnus nepalensis D. Don, Albizia sp and Prunus cerasoides D. Don were also found in the surrounding forest. Pine forest soil is brownish in colour and loamy sand in texture. Pine needles form the major mass of litter in this forest along with herbaceous plants in intact form or semi decomposed condition. Open canopy in pine forest allows sufficient light to reach the forest floor with an intensity ranging from $150-350 \mu \mathrm{mol}$ photons $\mathrm{m}^{-2} \mathrm{~s}^{-1}$.

\section{MATERIALS AND METHODS}

\section{Soil Analysis}

Soil samples were collected on a monthly basis from November 2015 to October 2016. 10 random sites were selected from each forest. $500 \mathrm{~g}$ of soil was collected from the upper layer of the soil $(0-2 \mathrm{~cm})$ by removing the surface litter at each site. Soil samples were soaked in deionized water (1:5 proportions) to prepare a soil solution for the measurements of $\mathrm{pH}$ and electrical conductivity which were read using digital pH meter (model - 101) and conductivity meter (model - 611). Soil texture was estimated by hydrometer method (Bouyoucos, 1962). Moisture content of the soil was determined by oven dry basis (drying $10 \mathrm{~g}$ soil in a hot air oven at $105^{\circ} \mathrm{C}$ ). Soil organic carbon was estimated following the method by Walkley \& Black (1934) while total nitrogen, phosphorus and potassium were estimated as per Jackson (1967).

\section{Algal Analysis}

About $10 \mathrm{~g}$ of each soil sample was placed in a flask and diluted 100-fold with distilled water. Different culture media (BBM, BG-11 and Gulliard medium) in liquid or solidified form with $1.5 \%$ agar were used for culture and isolation of the algae. The number of algae appeared in culture media were determined by counting algal colonies 
and estimated per $1 \mathrm{~g}$ dry weight (d.w.) of soil. Colonies of Chlorophyta $(\mathrm{CH})$, Xanthophyceae (X) and Eustigmatophyceae (E) (hereinafter $\mathrm{CH}+\mathrm{X}+\mathrm{E}$ ) were counted together, Cyanobacteria (CY) and Bacillariophyceae (D) were counted separately (Zancan \& al., 2006).

All the isolated algae were observed under trinocular microscope (Olympus BX41) and identified to the possible lower taxonomic level by consulting standard books and monographs like Fritsch (1935), Desikachary (1959), Philipose (1967), Prescott (1982), Gandhi (1998) and John \& al. (2002). Taxonomy was updated using the online database Algae Base (Guiry \& Guiry, 2017) and ADIAC (Automatic Diatom Identification and Classification) Diatom image database funded by the European Marine Science and Technology (MAST) programme.

Species diversity was calculated using the ShannonWiener diversity index (1963) following the formulae,

$$
H^{\prime}=\sum_{\mathrm{i}=1}^{\mathrm{s}} p_{i} \ln p_{i}
$$

Where $\mathrm{p}_{\mathrm{i}}=\mathrm{n}_{\mathrm{i}} / \mathrm{N}, \mathrm{n}_{\mathrm{i}}=$ number of individuals of the $\mathrm{i}^{\text {th }}$ species; $\mathrm{N}=$ total number of individuals of all the species.

\section{Statistical Analyses}

Values for different physico-chemical parameters and algal abundance were obtained on the basis of mean of ten independent samples. The data were statistically analysed using ANOVA with Microsoft Office Excel. nMDS (nonmetric multidimensional scaling) ordination plot was incorporated to detect the similarities of algal species in the two forests. ANOSIM (Analysis of similarities) was performed to obtain the significance of difference for species composition by using Bray Curtis distance measure permutation of 9999. ANOSIM used the procedure of comparing similarity between groups whether is greater than or equal to similarity within the groups. The test statistic $\mathrm{R}$ is calculated as

$$
R=\frac{r B-r W}{\mathrm{n}(\mathrm{n}-1) / 4}
$$

Where $r B$ is the average of rank similarities from different groups, $r W$ is the average of rank similarities within groups and $n$ is the total number of samples. The value $\mathrm{R}$ ranges from -1 to +1 . These analysis were carried out in PAST software version 1.93 .
Principal Component Analysis (PCA) was employed to compare the two forest types with soil characteristics in the first analysis and a second analysis was conducted to compare the algal community characteristics on the abundance of taxa identified belonging to different algal classes. PCA was performed using statistical package XLSTAT version 2009.

\section{RESULTS}

\section{Soil Characteristics}

All the soil parameters, except for phosphorus varied significantly $(p<0.05)$ in two forest types. In both the forests, $\mathrm{pH}$ of the soil was acidic and ranged from 4.836.63. Moisture content and water holding capacity of soil in sacred grove were higher than the soil in the pine forest whereas soil temperature in pine forest was higher than that of sacred grove.

Organic carbon and total nitrogen were higher in sacred grove compared to that in pine forest. Organic carbon was higher during March to May while total nitrogen was higher during June to September in both the forests. Exchangeable potassium and electrical conductivity were also higher in sacred grove than in pine forest while available phosphorus was recorded to be higher in pine forest than sacred grove. Monthly variations for electrical conductivity was comparatively less in the two forest types, potassium and phosphorus were higher during June to August (Table $1 \&$ Figure 2).

\section{Diversity and Composition}

Based on morphological characteristics, 124 algal taxa were identified from the two forests. Out of 124 taxa, 71 were recorded exclusively in sacred grove and 63 in pine forest, while only 10 taxa were noted to be common in the two forests (Table 2). Soil in the sacred grove supported diverse algal community mostly dominated by Cyanobacteria and green algal species. Pine forest revealed lesser number of taxa as compared to sacred grove, while diatoms were observed to be in abundant in this forest.

The average abundance of soil algae varied from $38 \times 10^{3}$ to $4200 \times 10^{3}$ algal cells $\mathrm{g}^{-1}$ soil (d.w). Members of $\mathrm{CH}+\mathrm{X}+\mathrm{E}$ accounted for high abundance $\left(3500 \times 10^{3} \mathrm{~g}^{-1}\right.$ soil d. w) in almost all the samples analyzed from the two forests. Cyanobacteria members were abundant in sacred grove $(850 \mathrm{x}$ $10^{3} \mathrm{~g}^{-1}$ soil d. $\left.\mathrm{w}\right)$ than in pine forest $\left(<500 \times 10^{3} \mathrm{~g}^{-1}\right.$ soil $\mathrm{d}$. $\mathrm{w}$ ) while diatoms were comparatively higher in pine forest 


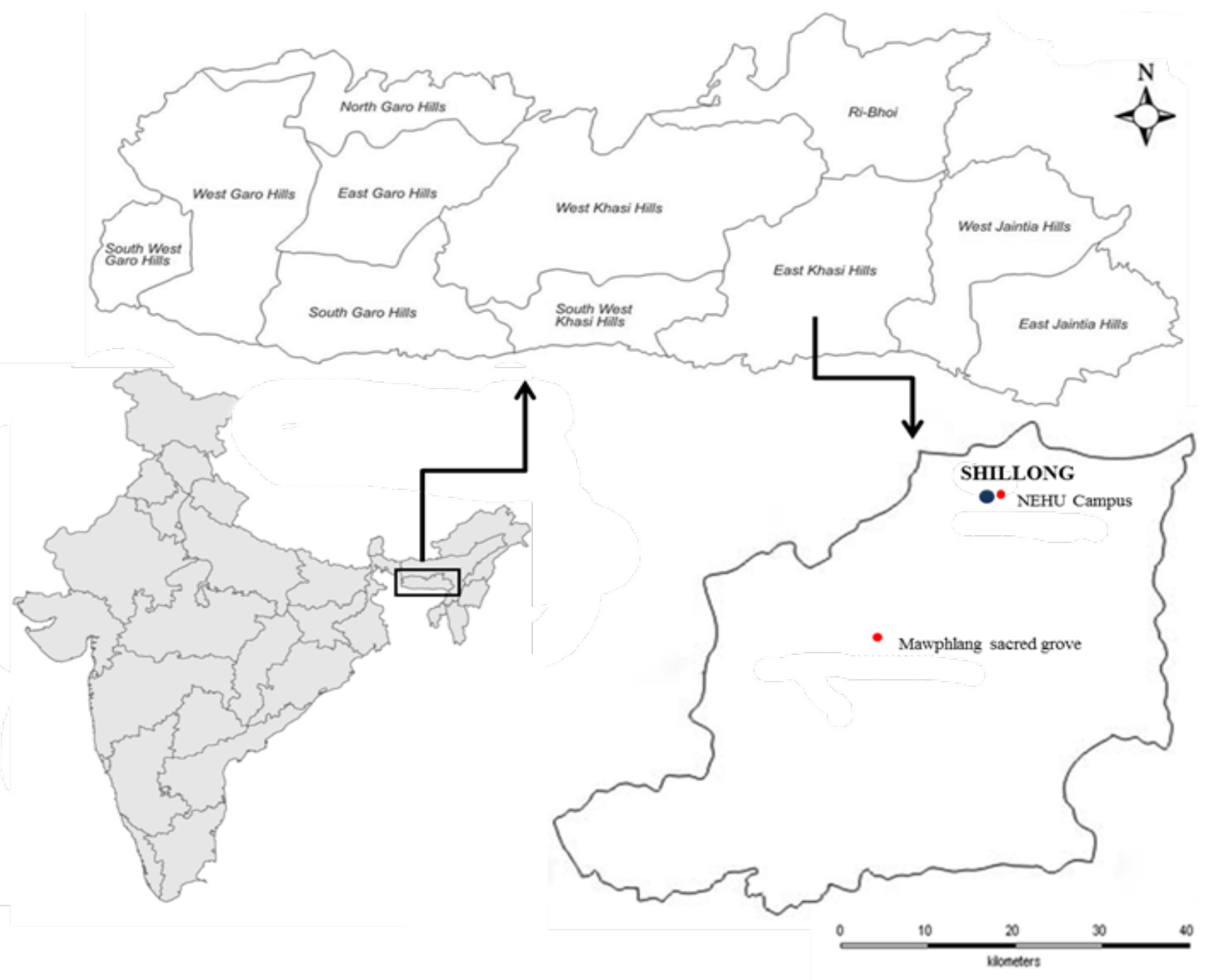

Fig. 1. Map showing location of the two forest types in East Khasi Hills District of Meghalaya

Table 1. Range of soil parameters in the sacred grove and pine forest (values in parenthesis denotes mean and standard deviation)

\begin{tabular}{|c|c|c|c|c|}
\hline Parameters & Pine Forest & Sacred Grove & F-value & P-value \\
\hline $\mathrm{pH}$ & $5.15-6.63(5.71 \pm 0.49)$ & $4.83-5.23(5.01 \pm 0.17)$ & 20.95 & $0.0001^{\star}$ \\
\hline Temperature $\left({ }^{\circ} \mathrm{C}\right)$ & $14-32 \quad(24.25 \pm 7.16)$ & $8-24 \quad(17.25 \pm 5.95)$ & 6.77 & $0.01^{\star}$ \\
\hline Moisture content (\%) & $18.98-42.15(31.36 \pm 10.02)$ & $27.12-58.1(46.02 \pm 11.93)$ & 10.61 & $0.003^{*}$ \\
\hline Water holding capacity (\%) & $14.56-15.43(15.03 \pm 0.32)$ & $30.23-32.87 \quad(31.65 \pm 0.87$ & 3773.36 & $4.19 \mathrm{E}-26^{*}$ \\
\hline Conductivity $\left(\mathrm{mS}^{-1} / \mathrm{cm}\right)$ & $0.01 \quad(0.01 \pm 1.81 \mathrm{E}-18)$ & $0.02 \quad(0.04 \pm 3.62-18)$ & 17.18 & $0.0064^{\star}$ \\
\hline Organic carbon $(\%)$ & $0.78-2.56(1.76 \pm 0.59)$ & $1.76-3.98(2.40 \pm 0.67)$ & 6.07 & $0.02^{\star}$ \\
\hline Total nitrogen $(\%)$ & $0.09-0.18(0.13 \pm 0.02)$ & $0.17-0.29(0.22 \pm 0.04$ & 34.79 & $6.17 \mathrm{E}-06^{*}$ \\
\hline Available Phosphorus (\%) & $\begin{array}{l}0.002-0.0067 \\
(0.0034 \pm 0.001)\end{array}$ & $\begin{array}{l}0.002-0.0045 \\
(0.003 \pm 0.0009)\end{array}$ & 0.39 & 0.53 \\
\hline Exchangeable Potassium (\%) & $0.01-0.02(0.01 \pm 0.005)$ & $0.02-0.03(0.02 \pm 0.007)$ & 15.62 & $0.0006^{*}$ \\
\hline
\end{tabular}

*Show statistical significance levels at $0.05 \mathrm{p}, 0.01 \mathrm{p}$ and $0.001 \mathrm{p}$ levels. 

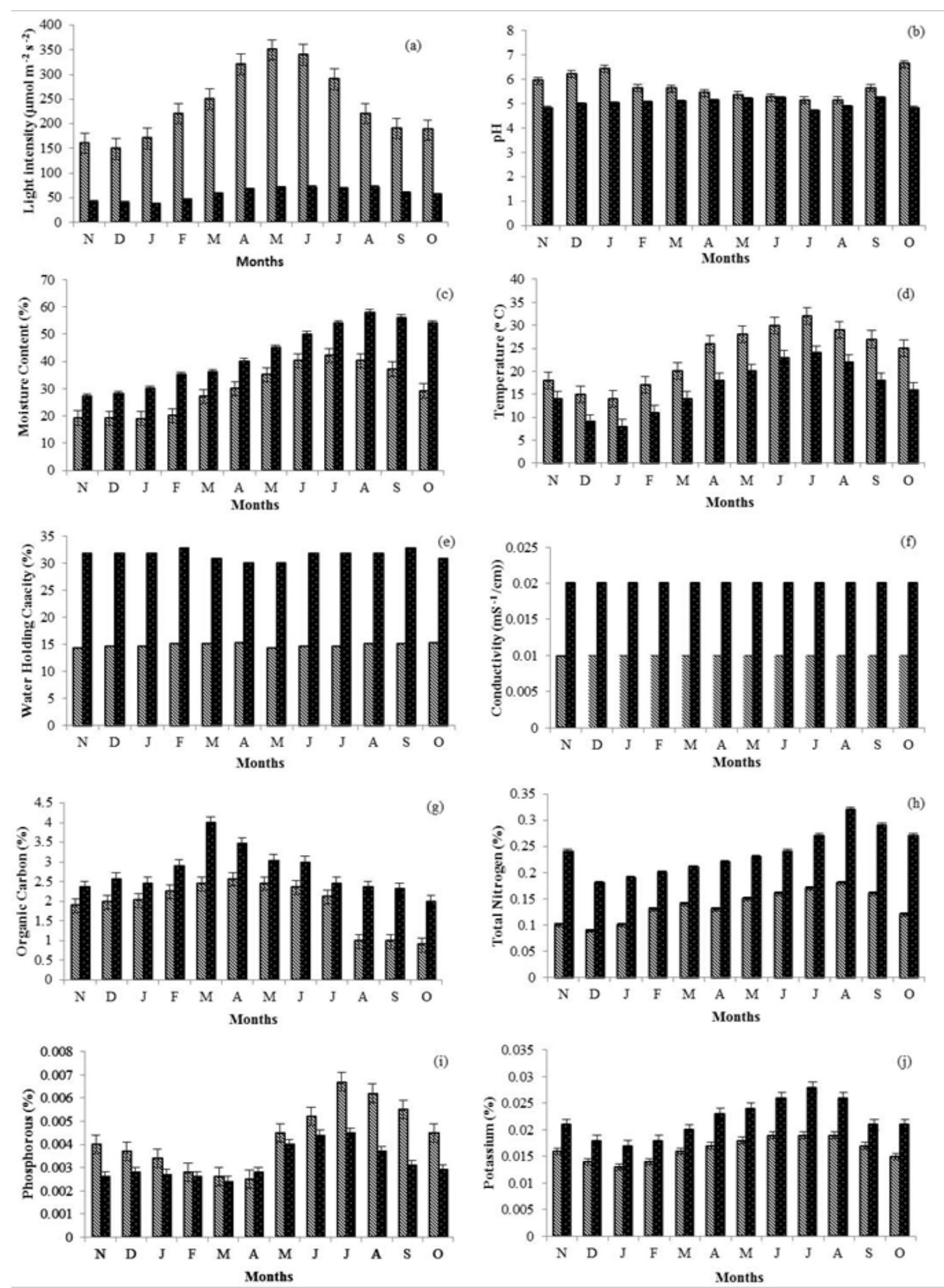

Fig. 2. Temporal and spatial variation of (a). light (b). $\mathrm{pH}$ (c). moisture content (d). temperature (e). water holding capacity (f). conductivity (g). organic carbon (h). total nitrogen (i). phosphorous and (j). potassium in two forest. (\$) indicates pine forest and (汭 sacred grove. 
Table 2. List of algae recorded from forest floor of sacred grove and pine forest

\begin{tabular}{|c|c|c|}
\hline Name of the species & Pine Forest & Sacred Grove \\
\hline \multicolumn{3}{|l|}{ Cyanobacteria } \\
\hline Anabaena catenula Kützing ex Bornet \& Flahault & + & + \\
\hline Anabaena constricta (Szafer) Geitler & + & - \\
\hline Anabaena oscillariodes Bory & - & + \\
\hline Anabaena spiroides Klebahn & + & - \\
\hline Aphanocapsa elachista West \& G.S.West & - & + \\
\hline Cylindrospermum michailovskoense Elenkin & - & + \\
\hline Cylindrospermum muscicola Kützing ex Bornet \& Flahault & - & + \\
\hline Gloeocapsa alpina Nägeli & - & + \\
\hline Gloeocapsa decorticans (A.Braun) P. Richter & + & - \\
\hline Gloeothece tepidariorum (A. Braun) Lagerheim & - & + \\
\hline Lyngbya lagerheimii Gomont ex Gomont & - & + \\
\hline Lyngbya semiplena J. Agardh ex Gomont & - & + \\
\hline Lyngbya spiralis Geitler & + & - \\
\hline Microcoelous sp & - & + \\
\hline Nostoc carneum C. Agardh ex Bornet \& Flahault & - & + \\
\hline Nostoc commune Vaucher ex Bornet \& Flahault & - & + \\
\hline Nostoc pruniforme C. Agardh ex Bornet \& Flahault & + & - \\
\hline Oscillatoria curviceps C. Agardh ex Gomont & + & - \\
\hline Oscillatoria germinata Schwabe ex Gomont & - & + \\
\hline Oscillatoria limosa C. Agardh ex Gomont & - & + \\
\hline Oscillatoria nigra Vaucher ex Gomont & - & + \\
\hline Phormidium inundatum Kützing ex Gomont & + & - \\
\hline Schizothrix lateritia Gomont & - & + \\
\hline Schizothrix telephoroides Gomont & + & - \\
\hline Scytonema mirabile Bornet & - & + \\
\hline Scytonema ocellatum Lyngbye ex Bornet\&Flahault & - & + \\
\hline Stigionema ocellatum Thuret ex Bornet \& Flahault & - & + \\
\hline Symploca muscorum Gomont ex Gomont & - & + \\
\hline Synechococcus aeruginosus Nägeli & + & - \\
\hline Westiellopsis sp & - & + \\
\hline \multicolumn{3}{|l|}{ Bacillariophyceae } \\
\hline Achnanthes lanceolata (Brébisson ex Kützing) Grunow & - & + \\
\hline Achnanthidium minutissimum (Kützing) Czarnecki & - & + \\
\hline Amphora elliptica (Agardh) Kützing & + & - \\
\hline Cocconeis placentula Ehrenberg & - & + \\
\hline Cymbella affinis Kützing & + & - \\
\hline Cymbella cistula (Ehrenberg) O. Kirchner & + & - \\
\hline Cymbella leptoceros (Ehrenberg) Kützing & - & + \\
\hline Cymbella naviculiformis Auerswald ex Heiberg & + & - \\
\hline Diadesmis contenta (Grunow) D.G. Mann & - & + \\
\hline Eunotia crista-galli Cleve & + & - \\
\hline
\end{tabular}


Eunotia exigua (Brébisson ex Kützing) Rabenhorst

Gomphonema lanceolatum Kützing

Gomphonema olivaceum (Hornemann) Brébisson

Gomphonema parvulum (Kützing) Kützing

Hantzschia abundans Lange-Bertalot

Hantzschia amphioxys (Ehrenberg) Grunow

Luticola mutica (Kützing) D.G.Mann

Melosira varians $\mathrm{C}$. Agardh

Navicula confervacea (Kützing) Grunow

Navicula dicephala Ehrenberg

Navicula exigua (Gregory) Grunow

Navicula gastrum (Ehrenberg) Kützing

Neidium amphigomphus (Ehrenberg) Pfizer

Pinnularia hustedtii K. Mölder

Pinnularia mesolepta (Ehrenberg) W. Smith

Pinnularia substomatophora Hustedt

Surirella oregonica Ehrenberg

Surirella saxonica Auerswald ex Rabenhorst

Tabellaria fenesrata (Lyngbye) Kützing

Tryblionella parvula (W. Smith) T. Ohtsuka \& Y. Fujita

\section{Chlorophyceae}

Asterococcus superbus (Cienkowski)Scherffel

Binuclearia sp

Bracteacoccus grandis H.W.Bischoff \& Bold

Bracteacoccus minor (Schmidle) ex Chodat

Chlamydomonas deasonii Ettl

Chlamydomonas snowiae Printz

Chlorococcum acidum P.A. Archibald \& Bold

Chlorococcum echinozygotum Starr

Chlorococcum sp

Chlorolobion braunii (Nägeli) Komarek

Chlorosarcinopsis gelatinosa Chantanachat \& Bold

Chlorosarcinopsis $\mathrm{sp}$

Coelastrella terestris (Reisigl) Hegewald \& N. Hanagata

Elliptochloris bilobata Tschermak-Woess

Gloeocycis ampla (Kützing) Rabenhorst

Gloeocystis polydermatica (Kützing) Hindak

Gloeocystis vesiculosa Nägeli

Leptosira sp

Microspora floccosa (Vaucher) Thuret

Microspora pachyderma (Wille) Lagerheim

Microspora tumidula Hazen

Neospongiococcum granatum Deason

Neospongiococcum vacuolatum Deason \& E.R.Cox 
Scenedesmus abundans (O.Kirchner) Chodat

Scenedesmus arcuatus (Lemmermann) Lemmermann

$\begin{array}{ll}- & + \\ + & - \\ - & + \\ - & + \\ - & + \\ - & + \\ + & - \\ - & +\end{array}$

Scenedesmus bijuga Kützing

Scenedesmus dimorphus (Turpin) Kützing

Scenedesmus quadricauda (Turpin) Brébisson

Scotiellopsis oocystiformis (J.W.G.Lund)Puncocharova \& Kalina

Tetracystis pulchra R.M.Brown \& Bold

Tetraspora lacustris Lemmermann

\section{Trebouxiophyceae}

Chlorella saccharophila (Krüger) Migula

Chlorella vulgaris Beyerrinck (Beijerinck)

Dictyochloropsis splendida Geitler

Monoraphidium contortum (Thurut) Komarkova-Legnerova

Monoraphidium graffithii (Berkeley) Komarkova-Legnerova

Monoraphdium tortile (West \& G .S. West)

Muriella decolour Vischer

Myrmecia bisecta Reisigl

Oocystis borgei J. W. Snow

Oocystis elliptica West

Oocystis lacustris Chodat

Podohedra saltans J. Neustupa

Pseudococcomyxa simplex (Mainx) Fott

Stichococcus bacillaris Nägeli

Trebouxia arboricola Puymaly

$+$

$+$

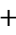

$+$

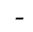

$+$

$+$

$+$

$+$

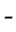

$+$

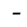

$+$

Klebsormidiophyceae

Klebsormidium crenulatum (Kützing) Lokhorst

Klebsormidium elegans Lokhorst

Klebsormidium flaccidum (Kützing) P.C.Silva, K.R.Mattox \& W.H.Blackwell

Klebsormidium fluitans (F.Gay) Lokhorst

Klebsormidium nitens (Kützing) Lokhorst

Zygnematophyceae

Cosmarium variolatum P. Lundell

Cylindrocystis brebissonii (Ralfs) De Bary

Mesotaenium macrococcum (Kützing ex Kützing) J. Roy \& Bisset

Mougeotia parvula Hassall

\section{Euglenophyceae}

Euglena gracilis G. A Klebs

Euglena hemichromata Skuja

Euglena oxyuris Schmarda

$\begin{array}{lr}+ & + \\ - & + \\ + & + \\ + & - \\ + & -\end{array}$

\section{Ulvophyceae}

Cladophora glomerata (Linnaeus) Kützing

Ulothrix minuta K. R Mattox and Bold

$+$

$$
+
$$

(1) 
Ulothrix tenerrima (Kützing) Kützing

\section{Eustigmatophyceae}

Eustigmatos vischeri D. J Hibberd

\section{Xanthophyceae}

Tribonema viride Pascher

Xanthonema quadrata (Pascher) P.C. Silva

(+ indicates presence, - indicates absence

Table 3. Pearson's Correlation coefficient ( $\mathrm{r}$ ) values obtained between different algal class diversity with light and different soil parameters. $(\mathrm{CH}+\mathrm{X}+\mathrm{E}-$ Chlorophyta + Xanthophyceae+ Eustigmatophyceae), $\mathrm{CY}$ - Cyanobacteria and D-Bacillariophyceae)

\begin{tabular}{lccc}
\hline Parameters & \multicolumn{3}{c}{ Diversity index } \\
\cline { 2 - 4 } & $\mathrm{CH}+\mathrm{X}+\mathrm{E}$ & $\mathrm{D}$ & $\mathrm{CY}$ \\
\hline Light intensity & $-0.74^{*}$ & $0.74^{*}$ & $-0.63^{*}$ \\
$\mathrm{pH}$ & $-0.49^{*}$ & $0.48^{*}$ & -0.37 \\
Temperature & -0.20 & $0.67^{\star}$ & 0.03 \\
Water holding capacity & $0.73^{*}$ & $-0.81^{*}$ & 0.67 \\
Moisture content & $0.57^{*}$ & -0.28 & $0.66^{*}$ \\
Conductivity & 0.29 & -0.53 & 0.32 \\
Carbon & 0.36 & -0.22 & $0.58^{*}$ \\
Nitrogen & $0.54^{*}$ & $-0.66^{*}$ & $0.57^{*}$ \\
Phosphorus & -0.37 & -0.07 & -0.36 \\
Potassium & 0.46 & $-0.66^{*}$ & 0.22 \\
\hline
\end{tabular}

${ }^{\star}$ Indicates significant at $\mathrm{p}<0.05$
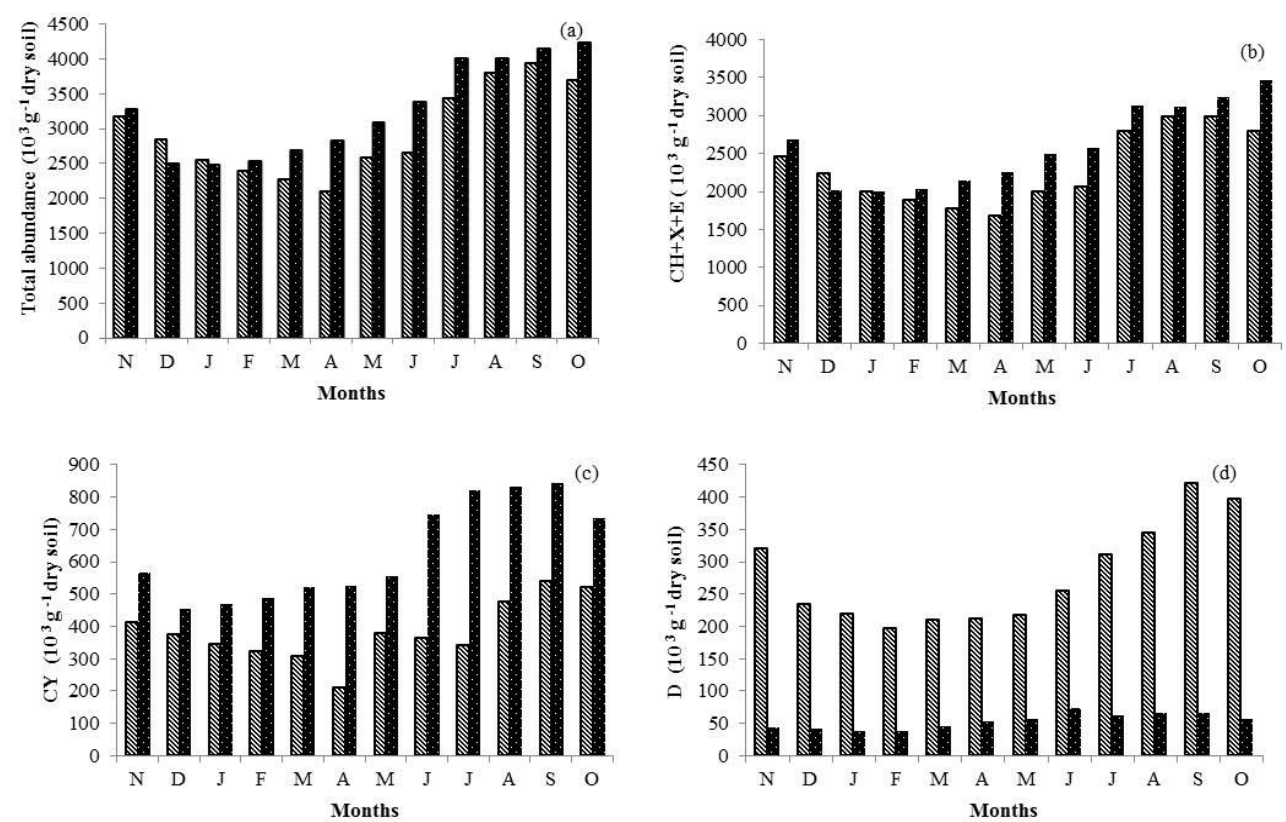

Fig. 3. Algal abundance in pine forest ( $)$ and sacred grove (-). (a). total algal abundance (b). abundance of $\mathrm{CH}+\mathrm{X}+\mathrm{E}$ (green algae+Xanthophyceae+Eustigmatophyceae) (c). abundance of CY (Cyanobacteria) (d). abundance of D (Bacillariophyceae). 
$\left(<450 \times 10^{3} \mathrm{~g}^{-1}\right.$ soil d. w). Diatoms were less abundant in soil of sacred grove $\left(<50 \times 10^{3} \mathrm{~g}^{-1}\right.$ soil d. w) and rare during December and January (Fig. 3). In sacred grove, members of $\mathrm{CH}+\mathrm{X}+\mathrm{E}$ contributed about $80 \%$ of the total abundance of the algal community distributed throughout the year, while Cyanobacteria accounted for 18\%-21 \% and diatoms contributed less than $2 \%$ to the algal community structure. In pine forest $\mathrm{CH}+\mathrm{X}+\mathrm{E}$ amounted for $72 \%-80 \%$, Cyanobacteria of $12 \%-14 \%$ while diatom members contributed $15 \%-25 \%$ throughout the year.

Overall diversity was higher in sacred grove in the range of 2.81-3.54 compared to that of 2.36-3.00 in pine forest. Sacred grove was recorded to have higher $\mathrm{CH}+\mathrm{X}+\mathrm{E}$ algal diversity of 2.39-3.07 than pine forest of 1.44-2.35. Cyanobacteria diversity in sacred grove varied from 1.932.75 while in pine forest it varied from 1.55-2.21. Diatoms diversity on the other hand was higher in pine forest with 1.75-2.38 compared to that in sacred grove with 0.99-1.74 (Fig. 4).

Application of nMDS ordination, clustered the samples from into two different groups clearly indicating that the species composition in the two forest types were different from each other. The algal community in both the forest types occupied large ordination space which could be due to the diverse algal composition (Fig. 5). ANOSIM showed significant difference in species composition (mean rank within groups $=70.81$, mean rank between groups $=200.5, \mathrm{R}=0.94$ and $\mathrm{p}=0.0001$ ).

The algal community in sacred grove could be distinguished from that in pine forest by the presence of species like Binuclearia sp, Scotiellopsis oocystiformis, Eustigmatos vischeri, Cladophora glomerata, Trebouxia arboricola, Chlorosarcinopsis gelatinosa, Elliptochloris bilobata, Neospongiococcum vacuolatum, Euglena oxyuris, Euglena gracilis Cyanobacteria like Stigionema ocellatum, Scytonema ocellatum, Lyngbya semiplena, Oscillatoria limosa, and Westiellopsis sp. Diatoms like Achnanthes lanceolata, Achnanthidium minutissimum, Cocconeis placentula and Diadesmis contenta were mostly observed. Species of Amphora elliptica, Luticola mutica, Pinnularia substomatophora, Neidium amphigomphus, Tryblionella parvula, Klebsormidium nitens, Tetracystis pulchra, Pseudococcomyxa simplex and Stichococcus bacillaris were more abundant in pine forest.

\section{Algal Community and Soil Variables}

Correlation between $\mathrm{CH}+\mathrm{X}+\mathrm{E}$ diversity index with light and different soil parameters showed a significant positive correlation with water holding capacity and moisture content and negative correlation with light intensity and $\mathrm{pH}$. Cyanobacteria diversity index showed a significant positive correlation with moisture content, carbon and nitrogen. A significant positive correlation was obtained between diversity of diatoms and light intensity, $\mathrm{pH}$ and temperature, while negative correlation observed with water holding capacity, nitrogen and potassium (Table 3).

Principal Component Analysis (PCA) employed to compare the soil characteristics of two forest types accounted for $70 \%$ variation. Sacred grove soil could be distinguished from pine forest soil with higher water holding capacity and higher organic carbon, total nitrogen, potassium and phosphorus content. The first principal component analysis represented $48 \%$ of the total variable which primarily reflected the effect of water holding capacity, moisture content, organic carbon, total nitrogen, phosphorus, potassium and electrical conductivity while the second PC (22\%) reflected the effect of temperature and light intensity. The third PC (not shown) reflected the $\mathrm{pH}$. The first two components of the variance analysis based on algal community variables justified $64 \%$ of the variance in the data. In this analysis pine forest were grouped together because of limited number of Cyanobacteria and a higher number of diatoms in all the months. The intra-sites difference was greater in sacred grove than in pine forest (Fig. 6).

\section{DISCUSSION}

In both the forest types, $\mathrm{pH}$ of the soil was acidic. Chiu \& al., (2005) reported that acidity of forest soil could be due to nature of organic matter and parent rock material. Higher amount of moisture in a soil depends on relatively dense shade (Kara \& Bolat, 2008), abundant vegetation and thick layer of litter add to lower of soil temperature (Devi \& Dkhar, 2014), thus the decrease of soil moisture content and increase of temperature in pine forest compared to sacred grove maybe due to this fact. Radhapriya \& al., (2013) reported that dense canopy along with higher input of litter resulted in maximum storage of carbon and nitrogen in the mineral soil. This could explain the presence of higher amount of organic carbon and total nitrogenin sacred grove compared to that in pine forest throughout the sampling months. Ollinger \& al., (2002) reported potential influence of vegetation on soil moisture and nutrient content through many pathways. 
(a)

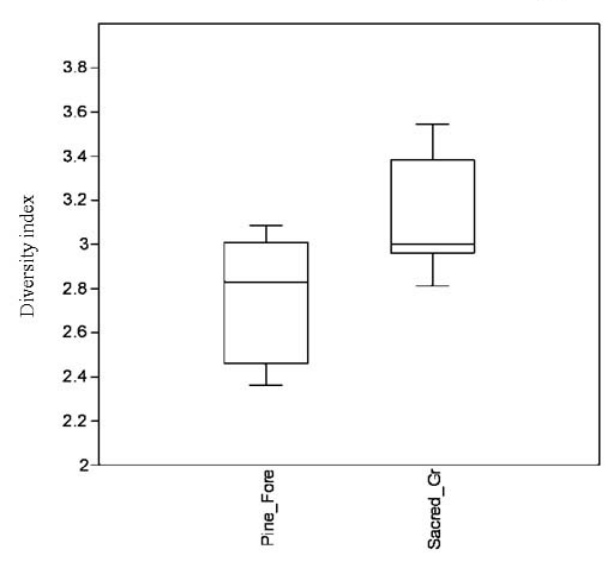

(b)

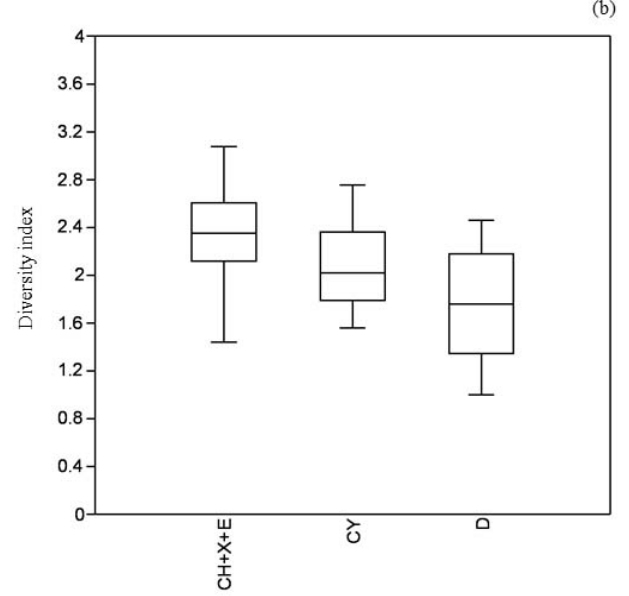

Fig 4. Boxplot of Shannon diversity index (a) pine forest and sacred grove (b). $\mathrm{CH}+\mathrm{X}+\mathrm{E}$ (Chlorophyta+Xanthophyceae+Eus tigmatophyceae), CY (Cyanobacteria) and D (Bacillariophyceae).

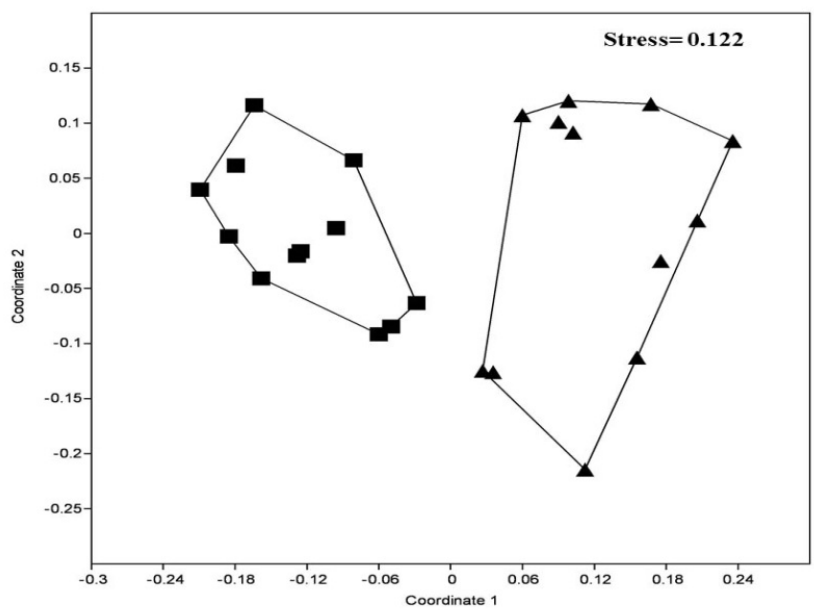

Fig 5. nMDS ordination diagram of the two forest according to species composition. Square ( $\boldsymbol{\square})$ indicates pine forest and triangle $(\mathbf{\Lambda})$ signifies sacred grove.
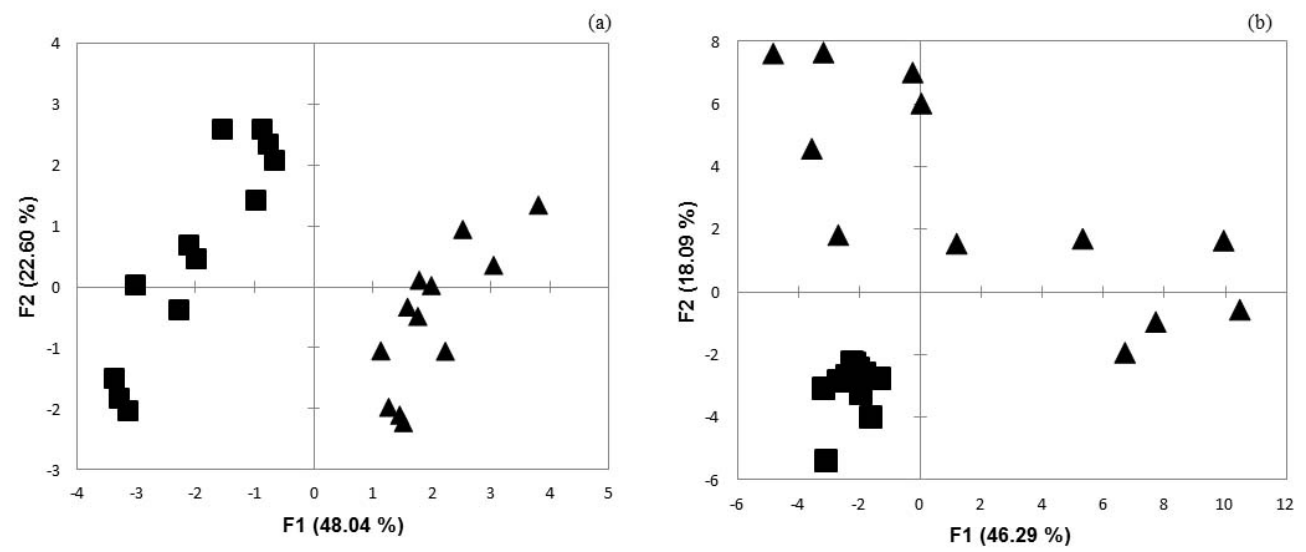

Fig. 6. Ordination diagram based on (a). light intensity, pH, temperature, moisture content, water holding capacity, conductivity, organic carbon, total nitrogen, potassium and phosphorous (b). algal community variables, total algal abundance, $\mathrm{CH}+\mathrm{X}+\mathrm{E}$ (Chlorophyta+Xanthophyceae+Eustigmatophyceae), CY (Cyanobacteria) and D (Bacillariophyceae. Square (घ) indicates pine forest and triangle $(\mathbf{\Lambda})$ signifies sacred grove. 



Plate 1. Cyanobacteria a. Anabaena oscillariodes Bory; b. Anabaena spiroides Klebahn; c. Cylindrospermum muscicola Kützing ex Bornet \& Flahault; d. Gloeocapsa alpina Nägeli; e. Gloeocapsa decorticans Kützing ex Bornet \& Flahault; f. Lyngbya lagerheimii Gomont ex Gomont; g. Microcoelous sp; h. Nostoc carneum C. Agardh ex Bornet \& Flahault; i. Oscillatoria curviceps C. Agardh ex Gomont; j. Oscillatoria germinata Schwabe ex Gomont; k. Oscillatoria limosa C. Agardh ex Gomont; 1. Oscillatoria nigra Vaucher ex Gomont; m. Schizothrix lateritia Gomont; n. Schizothrix telephoroides Gomont; o. Stigionema ocellatum Thuret ex Bornet \& Flahault; p. Westiellopsis sp. (Scale bar - $10 \mu \mathrm{m}$ ). 

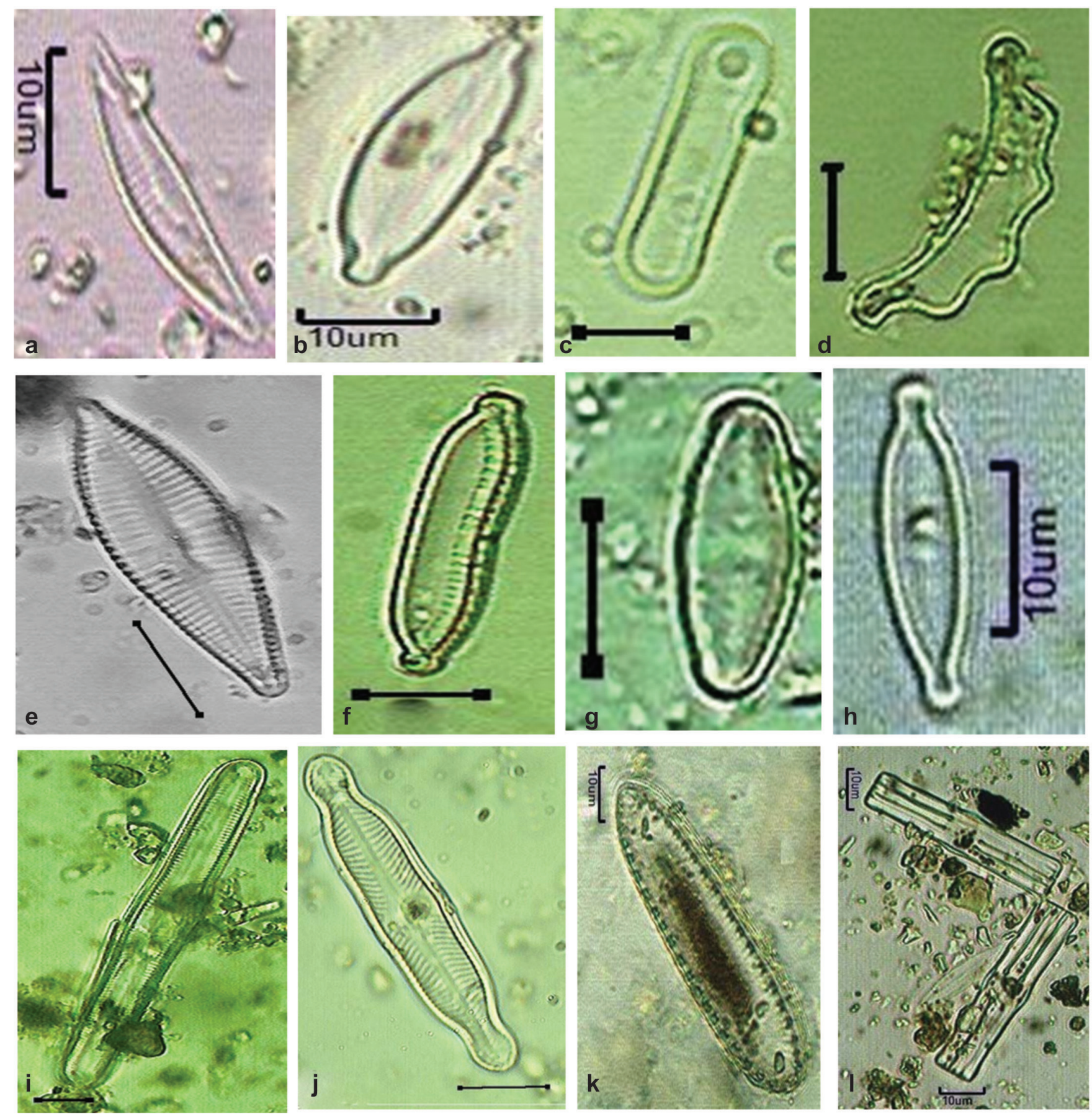

Plate 2. Bacillariophyceae: a. Cymbella affinis Kützing; b. Cymbella naviculiformis Auerswald ex Heiberg; c. Diadesmis contenta (Grunow) D.G. Mann; d. Eunotia crista-galli Cleve; e. Gomphonema parvulum (Kützing) Kützing; f. Hantzschia amphioxys (Ehrenberg) Grunow; g. Luticola mutica (Kützing) D.G. Mann; h. Navicula exigua (Gregory) Grunow; i. Pinnularia hustedtii K. Mölder; j. Pinnularia mesolepta (Ehrenberg) W. Smith; k. Surirella saxonica Auerswald ex Rabenhorst; 1. Tabellaria fenesrata (Lyngbye) Kützing. (Scale bar - $10 \mu \mathrm{m})$. 

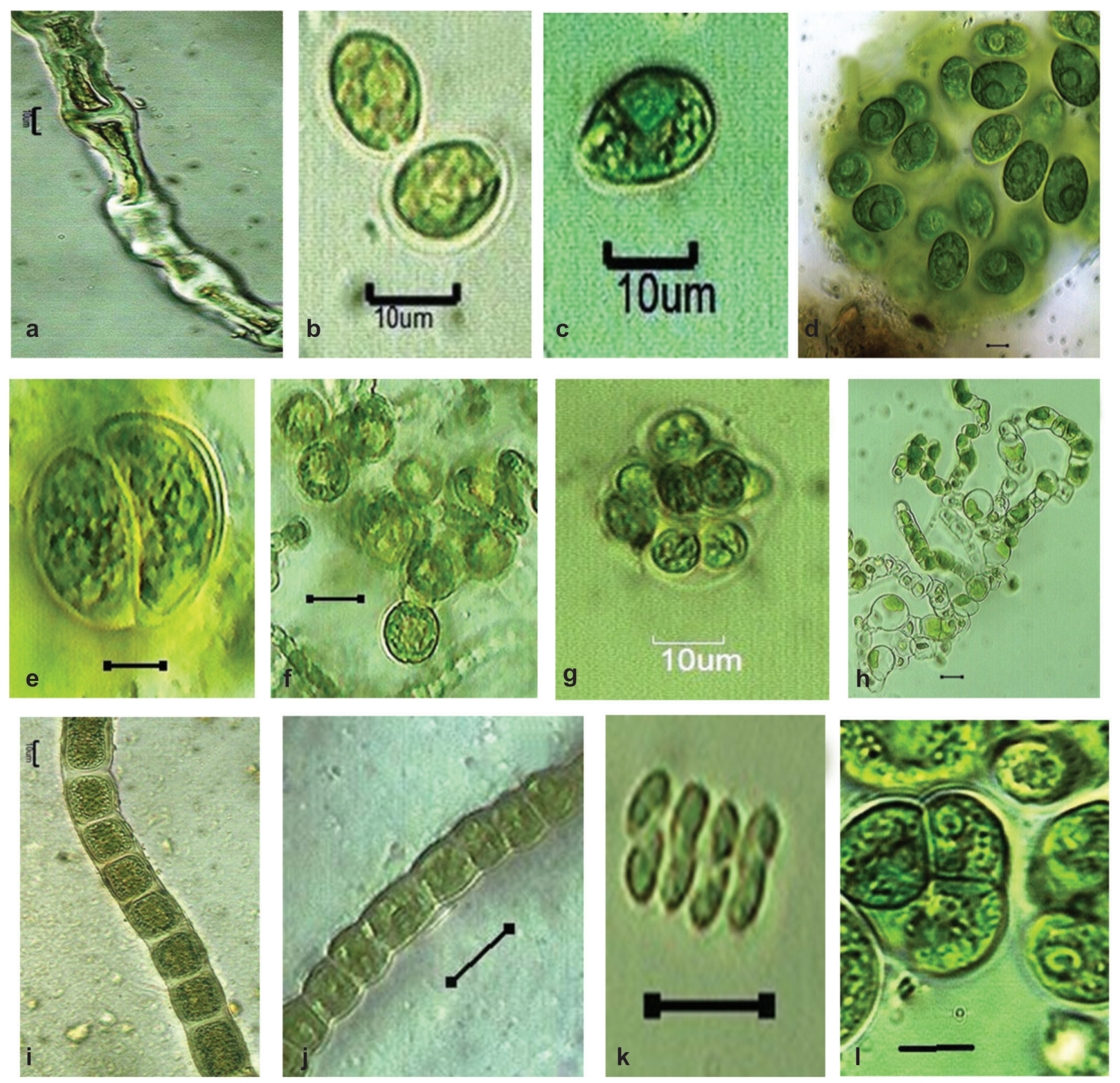

Plate 3. Chlorophyceae: a. Binuclearia sp; b. Chlamydomonas deasonii Ettl; c. Chlamydomonas snowiae Printz; d. Chlorococcum sp; e. Chlorosarcinopsis sp; f. Elliptochloris bilobata Tschermak-Woess; g. Gloeocystis vesiculosa Nägeli; h. Leptosira sp; i. Microspora floccosa (Vaucher) Thuret; j. Microspora tumidula Hazen; k. Scenedesmus arcuatus (Lemmermann) Lemmermann; 1. Tetracystis pulchra R.M. Brown \& Bold. (Scale bar - $10 \mu \mathrm{m}$ ). 

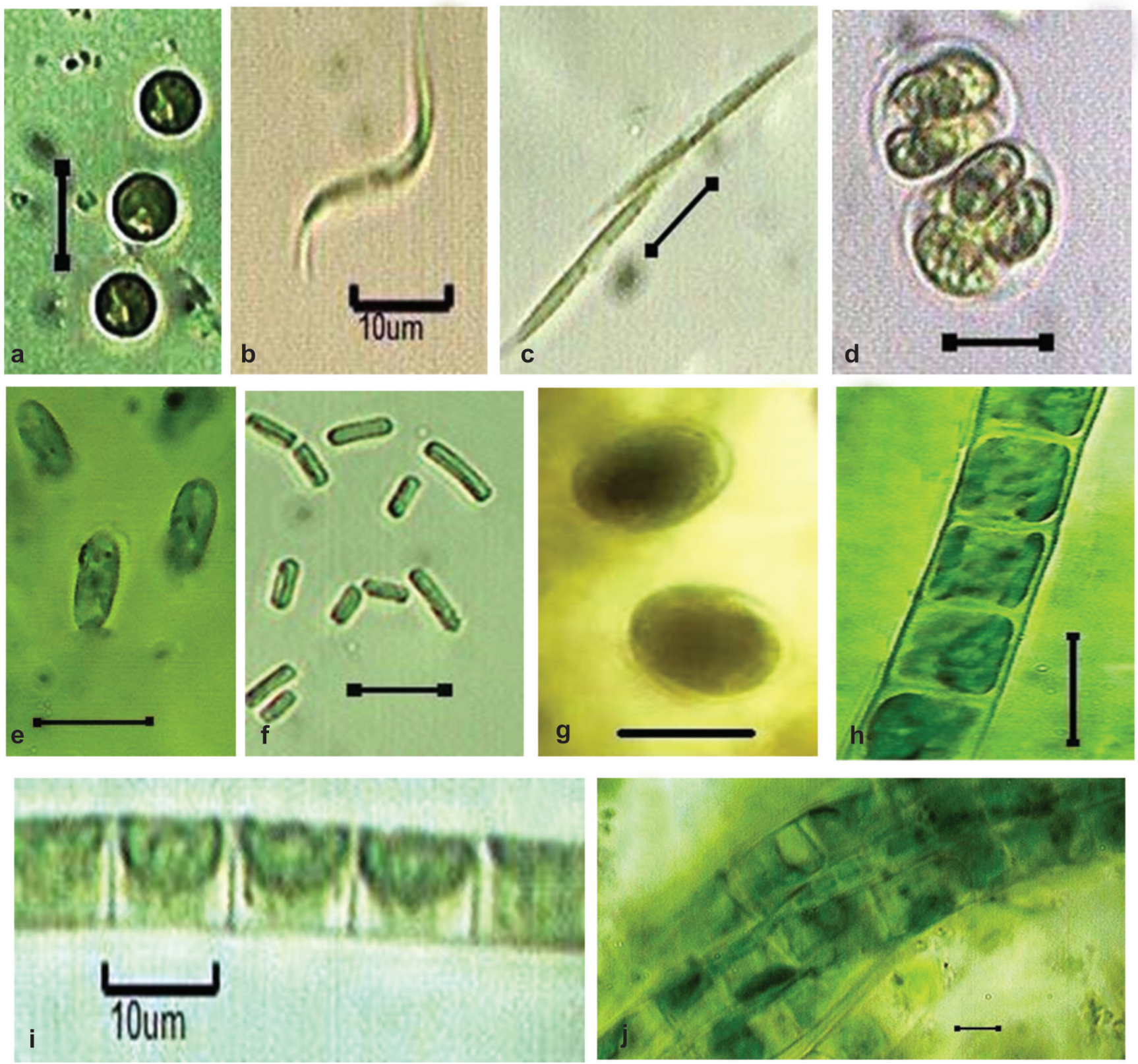

Plate 4. Trebouxiophyceae: a. Chlorella vulgaris (Beyerrinck)Beijerinck; b. Monoraphidium contortum (Thurut) KomarkovaLegnerova; c. Monoraphidium graffithii (Berkeley) Komarkova-Legnerova; d. Oocystis lacustris Chodat; e. Pseudococcomyxa simplex (Mainx) Fott; f. Stichococcus bacillaris Nägeli; g. Trebouxia arboricola Puymaly. Klebsormidiophyceae: h. Klebsormidium crenulatum (Kützing) Lokhorst; i. Klebsormidium flaccidum (Kützing) P.C. Silva; j. Klebsormidium fluitans (F. Gay) Lokhorst. (Scale bar - $10 \mu \mathrm{m}$ ). 

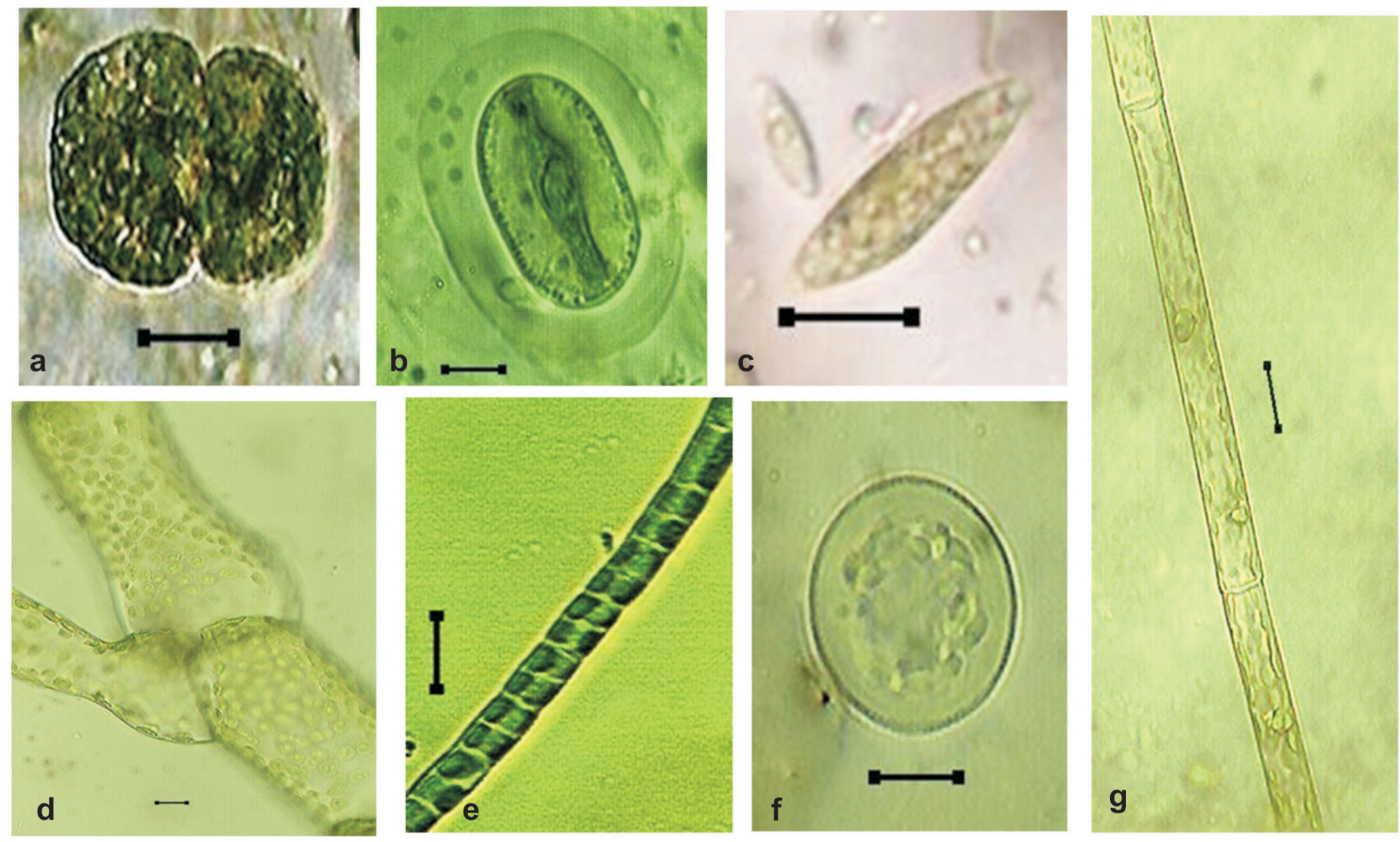

Plate 5. Zygnematophyceae: a. Cosmarium variolatum P. Lundell: b. Mesotaenium macrococcum (Kützing ex Kützing) J. Roy \& Bisset; Euglenophyceae: c. Euglena gracilis G. A Klebs.; Ulvophyceae: d. Cladophora glomerata (L.) Kützing; e. Ulothrix tenerrima (Kützing) Kützing; Eustigmatophyceae: f. Eustigmatos vischeri D. J Hibberd.; Xanthophyceae: g. Tribonema viride Pascher. (Scale bar - $10 \mu \mathrm{m}$ ).

According to Neustupa \& Skaloud $(2008,2010)$ diversity is more in open areas where light is the main influence, but observations by Ray \& Thomas, (2013) revealed that in teak plantations where trees remain leafless and the soil getting more exposed to sun light, a corresponding increase in soil algal diversity was not observed. Kharkongor \& Ramanujam, (2014) observed higher algal diversity in forests with closed canopy which is in conformity with the present observation that soil in the sacred grove with dense canopy supported diverse algal community mostly dominated by Cyanobacteria and green algal species. In the present study, higher soil moisture content in soil of sacred grove with dense canopy and higher carbon and nitrogen content harboured higher algal diversity as compared to pine forest.

Green algae were considered to be the most tolerant group to adverse soil conditions (Hoffmann \& al., 2007), however diverse species of these algae were observed in natural forest soil (Ray \& Thomas, 2013). Higher diversity of green algae in the present study was observed in more acidic and undisturbed sacred grove. $\mathrm{pH}$ is one of the most important factor affecting distribution of soil algae (Nayak \& Prasanna, 2007). It was reported that Cyanobacteria preferred neutral to alkaline conditions of the soil (De 1939) but in the present case, many species of Cyanobacteria were observed in acidic soil of sacred grove which could be attributed to high moisture content in the soil. Higher soil moisture content in the forest favours the algal growth and is the primary factor that determines blue green algae diversity in soil (Nisha \& al. 2007). Acidic nature of the soil on the other hand influenced the structure of diatom community. Diatoms species in sacred grove were very less compared to pine forest clearly supporting the fact that soil diatoms preferred to live in alkaline to neutral $\mathrm{pH}$ soil (Ray \& Thomas, 2013). 


\section{CONCLUSION}

The present study on diversity and ecology of soil algae in the two forest types, pointed out that soil in undisturbed broadleaf forest supported more diverse algal species than in pine forest. Green algal members (Chlorophyta) were the most dominant group in both the forest. In Mawphlang sacred grove, Cyanobacteria were another major contributor. Less number as well as abundance of diatoms was observed in undisturbed sacred grove as compared to pine forest which agrees with Heger \& al. (2011) that the diversity of diatom is much lower in undisturbed terrestrial environment. On the other hand pine forest shows higher proportion of diatoms than Cyanobacteria. The structure of soil algal communities in the two forest types thus is the result of the complex influence of vegetation and characteristics of soil in the forest floor.

\section{ACKNOWLEDGEMENTS}

The authors are thankful to North-eastern Hill University for providing financial assistance. Authors also acknowledge the Head of Botany Department for providing all the laboratory facilities. We are also thankful to Mr. Tambor Lyngdoh for giving the permission to collect samples from the sacred grove and the guides (John and Donkit) for their guidance and assistance during collection inside the grove.

\section{REFERENCES}

AUTOMATIC DIATOM IDENTIFICATION AND CLASSIFICATION 1999. Funded by the European MAST (Marine Science and Technology). Programme, Contract MAS3-CT97-0122.

BAKIEVA, G. R., L. S. KHAIKULLINA, L. A. GAISINA AND R. R. KABIROV 2012. Ecological floristic analysis of soil algae and Cyanobacteria on the Tra-Tau and Yurak- Tau Mounts, Bashkiria. Eurasian Soil Sci. 45: 873-881.

BHATNAGAR, A., M. B. MAKANDAR, M. K. GARG, AND M. BHATNAGAR 2008. Community structure and diversity of Cyanobacteria and green algae in the soils of Thar desert (India). J. Arid Environ. 72: 73-83.

BOHLEN, P. J., P. M. GROFFMAN, C. T. DRISCOLL, T. J. FAHEY AND T. G. SICCAMA 2001. Plant-Soil-Microbial interactions in a northern hardwood forest. Ecology 82: 965-978.

BOUYOUCOUS, G. J. 1962. Hydrometer method improved for making particle size analyses of soils. Agron. J. 54 (5): 464-465.
CHIU, C. Y., C. W. PAI AND K. L. YANG 2005. Characterization of phosphorous in subalpine forest and adjacent grassland soils by chemical extraction and phosphorous - 31 nuclear magnetic resonance spectroscopy. Pedobiologia 49: 655-663.

DE, P. K. 1939. The role of blue-green algae in nitrogen fixation in rice fields. Proc. R. Soc. Lond. (Biol.) 127: 121-139.

DESIKACHARY, T. 1959. Cyanophyta, I. C. A. R. Monograph on algae, New Delhi.

DEVI, H.R. AND M. S. DKHAR 2014. Comparative study on soil fungal diversity of Mawphlang sacred grove and disturbed forest North East India. Ind. J. Sci. Res. Tech. 2(5): 64-72.

EL-GAMAL, A. D., N. A. E. GHANEM, E. Y. EL-AYOUTY AND E. F. SHEHATA 2008. Studies on soil algal flora in Kafr El- Sheikh Governorate, Egypt. Egyptian J. Phycol. 9: 1-23.

FRITSCH , F. E. 1935. The structure and reproduction of algae : Vol. 1 and 2 Cambridge University Press. London.

FUJITA, Y. AND H. NAKAHARA 2006. Variations in the microalgal structure in paddy soil in Osaka, Japan: Comparison between surface and subsurface soils. Limnology 7: 83-91.

GANDHI, H. P. 1998. Fresh water diatom of Central Gujarat, Bishen Sing. Mahendra Pal Singh, Shiva Offset Press

GUIRY, M. D. AND G. M. GUIRY 2017. AlgalBase. World-wide electronic publication, National University of Ireland, Galway. http://www.algalbase.org

HEGER, T. J., F. STRAUB AND E. A. D., MITCHELL 2011 Impact of farming practices on soil diatoms and testate amoebae; A pilot study in the DOK- trial at Therwil, Switzerland. Eur. J. Soil Biol. 30: 1-16.

HOFFMAN, L., L. ECTOR, AND I. KOSTIKOV 2007. Algal flora from limed and unlimed forest soils in the Ardenne (Belgium). Syst. Geogr. Plants 77: 15-90

JOHN, D. M., B. A. WHITTON AND A. J. BROOK 2002. The freshwater algal flora of the British Isles: An identification guide to freshwater and terrestrial algae, Cambridge University Press, Cambridge.

JACKSON, M. 1967. Soil chemical analysis, Prentice Hall Inc. Englewood Cliffs, N. J.

KARA, O. AND I. BOLAT 2008. Soil microbial biomass C and $\mathrm{N}$ changes in relation to forest conversion in north western Turkey. Land Degrad. Dev. 9: 421-428.

KHARKONGOR, D. AND P. RAMANUJAM 2014. Diversity and species composition of subaerial algal communities in forested areas of Meghalaya, India. Int. J. Biodivers. 2014: $1-10$

LUKEOVA, A. 2001. Soil algae in brown coal and lignite postmining areas in Central Europe (Czech Republic and Germany). Restor. Ecol. 9: 341-350.

MANSOUR, H. A. AND A. S. SHAABAN 2010. Algae of soil surface of Wadi Al- Hitan protective area (World heritage site) El- Fayum Depression, Egypt. J. Am. Sci. 6: 243-255. 
MEGHARAJ, M., D. KANTACHOTE, I. SINGLETON AND R. NAIDU 2000. Effects of long term contamination of DDT on soil microflora with special reference to soil algae and algal transformation of DDT. Environ. Pollut. 09: 35-42.

NAYAK, S. AND R. PRASANNA 2007. Soil pH and its role in Cyanobacterial abundance and diversity in rice field soils. Appl. Ecol. Env. Res. 5: 103-113.

NEUSTUPA, J. AND P. SKALOUD 2008. Diversity of subaerial and Cyanobacteria on tree bark in tropical mountain habitats. Biologia 63: 806-812.

NEUSTUPA, J. AND P. SKALOUD 2010. Diversity of subaerial algae and Cyanobacteria growing on bark and wood in the lowland tropical forests of Singapore. Plant Ecol. Evol. 143:51-62.

NISHA, R., A. KAUSHIK AND C. P. KAUSHIK 2007. Effect of indegenious Cyanobacterial application on structural stability and productivity of an organically poor semi- arid soil. Geoderma 138: 49-56.

OLLINGER, S. V., M. L. SMITH, M. E. MARTIN, R. A. HALLET, C. L. GOOGALE AND J. D. ABER 2002. Regional variation in foliar chemistry and $\mathrm{N}$ cycling among forests of diverse history and composition. Ecology 83: 339-355.

PHILIPOSE, M. T. 1967. Chlorococcales, I.C.A.R., Krishi Bhawan, New Delhi.
PRESCOTT, G. W. 1982. Algae of Western Great Lakes Area, Michigan State University, Otto Koelt Science Publishers, Koenigstein, West Germany.

RADHAPRIYA, P., A. RAMACHANDRAN, P. DHANYA, K. REMYA AND P. MALINI 2013. An appraisal of physicochemical and microbiological characteristics of Nanmangalam Reserve Forest soil. J. Environ. Biol. 35: 1137-1144.

RAY, F. J. AND B. T. THOMAS 2013. Ecology and biodiversity of soil algae of Pathanamthitta District, Kerala, $\mathrm{PhD}$ thesis, Mahatma Gandhi University, Kerala.

REHAKOVA, K., Z. CHLUMSKA AND J. DOLEZAL 2011. Soil Cyanobacterial and micro algal diversity in dry mountains of Ladakh, North West Himalaya, as related to site, altitude and vegetation. Microb. Ecol. 62: 337-346.

SHANNON, C.E. AND W. WIEVER 1963. The Mathematical Theory of Communication, University of Illinios Press, Urbana.

WALKLEY, A. AND I. A. BLACK 1934. An examination of Degtjareff method for determining soil organic matter and a proposed modification of the chromic acid titration method. Soil Sci. 37: 29-37.

ZANCAN, S., R. TREVISAN AND M. G. PAOLETTI 2006. Soil algae composition under different agroecosystems in Northeastern Italy. Agric. Ecosyst. and Environ. 112: 1-12. 